\title{
Disorders of fructose metabolism
}

\author{
E. R. FROESCH \\ From the Metabolic Unit, Department of Medicine, University of Zurich, Switzerland
}

Fructose is and has always been an important nutriment for man. Table I shows the fructose content of some fruit and vegetables. As may be seen all of those listed contain glucose, fructose, and saccharose. Of these three sugars fructose is the sweetest, saccharose comes next, and glucose last. The daily fructose intake lies between 50 and $100 \mathrm{~g}$. It has risen enormously in the last 20 years due to the ever increasing consumption of sucrose which contains one molecule of glucose and one molecule of fructose.

TABLE I

GLUCOSE, FRUCTOSE, AND SACCHAROSE CONTENT OF SOME FRUIT AND VEGETABLES ${ }^{1}$

\begin{tabular}{|c|c|c|c|}
\hline \multirow[t]{2}{*}{ Source } & \multicolumn{3}{|c|}{ Percentage of Weight } \\
\hline & Glucose & Fructose & Saccharose \\
\hline Apple & $1 \cdot 7$ & $5 \cdot 0$ & $3 \cdot 1$ \\
\hline Pear & $2 \cdot 5$ & $5 \cdot 0$ & $1 \cdot 5$ \\
\hline Peach & $1 \cdot 5$ & $1 \cdot 6$ & $6 \cdot 6$ \\
\hline Lemon juice & 0.5 & 0.9 & $0 \cdot 1$ \\
\hline Blackberry & $3 \cdot 2$ & $2 \cdot 9$ & $0 \cdot 2$ \\
\hline Melon & $1 \cdot 2$ & 0.9 & $4 \cdot \overline{4}$ \\
\hline Tomato & 1.6 & $1 \cdot 2$ & 0.4 \\
\hline Carrot & $2 \cdot 1$ & $1 \cdot 0$ & $3 \cdot 1$ \\
\hline Vegetable marrow & $1 \cdot 1$ & $1 \cdot 2$ & 0.4 \\
\hline Sweet potato & 0.4 & 0.3 & $4 \cdot 1$ \\
\hline Potato & $0 \cdot 1$ & $0 \cdot 1$ & $0 \cdot 1$ \\
\hline Garden pea & $?$ & $?$ & $6 \cdot 7$ \\
\hline
\end{tabular}

${ }^{1}$ From Hardinge, Swarner, and Crooks (1965).

The role of fructose in the pathogenesis of the socalled diseases of civilization has not been established. Some claim that fructose is well tolerated by diabetics and of considerable help in their management (Mehnert, Mahrhofer, and Förster, 1964), whereas others tend to believe that the excessive intake of sucrose is at the root of a few major diseases of modern life such as obesity, diabetes, and atheromatosis (Yudkin, 1964; Yudkin and Roddy, 1964). Since the excessive intake of sucrose is almost always accompanied by intake of extra fat and extra calories in general, I do not share this latter view but rather believe that the imbalance between calorie intake and calorie output must be responsible for the 'explosion' of diabetes, obesity, and atheromatosis.

\section{THE MAJOR ROUTE OF FRUCTOSE METABOLISM}

Three organs share the 'specific' route of fructose metabolism by which more than $70 \%$ is utilized: the liver, kidney, and the mucosa of the small bowel (Fig. 1). Fructose is phosphorylated to fructose-1phosphate by the enzyme fructokinase, which also phosphorylates tagatose and sorbose (Leuthardt and Testa, 1950; Hers, 1952; Kuyper, 1959). Fructose-1phosphate is then split to phosphodihydroxyacetone and the non-phosphorylated triose glyceraldehyde. The enzyme which accomplishes this step, fructose-1phosphate aldolase, is present only in liver, kidney, and small bowel (Leuthardt, Testa, and Wolf, 1953; Hens and Kusaka, 1953). Fructose-1-phosphate aldolase has been investigated in detail by Penhoet and others who managed, among other remarkable biochemical achievements, to produce hybrids among subunits of fructose-1-phosphate and fructose-1, 6-diphosphate aldolases (Penhoet, Rajkumar, and Rutter, 1966; Christen, Göschke, Leuthardt, and Schmid, 1965). Whereas dihydroxyacetone phosphate now enters the glycolytic pathway, glyceraldehyde is still a product of the 'specific' fructose metabolism in these tissues. Glyceraldehyde may be metabolized by three pathways in liver tissue: (1) direct phosphorylation by the enzyme triose-kinase to glyceraldehyde phosphate (Hers and Kusaka, 1953; Heinz and Lamprecht, 1961); (2) oxidation to glycerol and subsequent phosphorylation by the enzyme glycerokinase (Wolf and Leuthardt, 1953); and (3) oxidation to glyceric acid and subsequent phosphorylation to phosphoglycerate by the enzyme glyceric acid kinase (Lamprecht and Heinz, 1958; Holzer and Holldorf, 1957).

According to recent investigations on enzyme activities in human liver by Heinz, Lamprecht, and Kirsch (1968), it appears likely that most of the glyceraldehyde formed during fructose metabolism is metabolized by triose-kinase.

The activities of fructokinase and of these other enzymes of fructose metabolism do not appear to be influenced to any great extent by insulin or insulin lack (Adelman, Spolter, and Weinhouse, 1966). The 


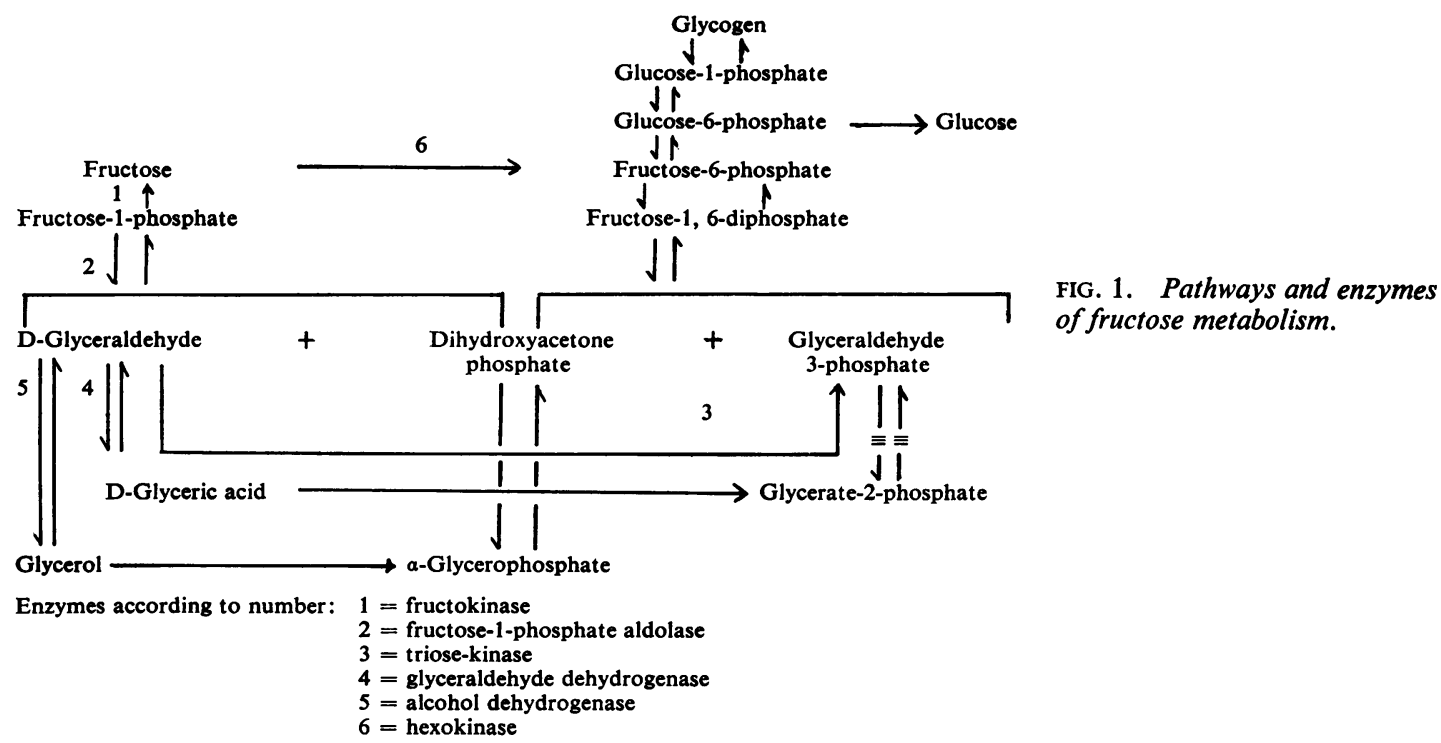

biological half life of fructose is of the order of magnitude of 18 minutes in normal subjects as well as in diabetics (Smith, Ettinger, and Seligson, 1953). It is not influenced by insulin. After oral fructose ingestion the venous blood fructose levels do not exceed $25 \mathrm{mg} / 100 \mathrm{ml}$ due to the rapid hepatic extraction of fructose.

\section{ABSORPTION OF FRUCTOSE FROM THE GUT}

Fructose is absorbed from the gut at a rate of approximately $43 \%$ of that of glucose (Cori, 1925). The process of fructose absorption is ill defined and was long thought to be one of passive diffusion. Fructose absorption is not inhibited by phlorizin and, unlike galactose, it does not compete with glucose for a common carrier. Metabolic poisons such as dinitrophenol appear to inhibit the conversion of fructose to glucose, but not the absorption of fructose itself (Crane, 1960). The absorption of sorbitol is slower still than that of fructose and an active component in the absorption of fructose from the gut cannot be entirely ruled out.

Fructose is absorbed from the gut in three forms: as fructose, as glucose, and as lactate. The percentage of these three varies according to the experimental animal and the quantity of fructose used. Conversion of fructose to glucose is by no means an essential part of its absorption. Thus patients with essential fructosuria, who are unable to phosphorylate fructose and to convert it to glucose in the mucosa of the small bowel, are perfectly able to absorb large quantities of fructose rapidly without any diarrhoea.

\section{MINOR ROUTES OF FRUCTOSE METABOLISM}

The ubiquitous enzyme hexokinase phosphorylates fructose to fructose-6-phosphate, an intermediate of glycolysis. However, hexokinase has a much higher affinity for glucose than for fructose. Therefore, fructose is only phosphorylated when no free glucose is present in the cell. This is true for erythrocytes and leucocytes which can oxidize fructose as well as glucose, but do so only in the absence of the latter hexose (Froesch, Wolf, Baitsch, Prader, and Labhart, 1963). In these cells the speed of glucose transport exceeds the rate of glucose phosphorylation so that free glucose is always present inside the cell. The situation is different in muscle. In the absence of insulin and below a blood glucose concentration of $50 \mathrm{mg} / 100 \mathrm{ml}$ no free glucose is present in the cytoplasm and the fructose entering the cell may be phosphorylated by hexokinase to fructose-6-phosphate (Froesch, 1965a; Morgan, Henderson, Regen, and Park, 1961). Adipose tissue appears to play a major role in fructose metabolism, particularly in patients in whom the specific pathway of fructose is deficient. Glucose transport appears to limit the rate of glucose metabolism under almost all circumstances in adipose tissue, so that no free glucose is ever present (Froesch and Ginsberg, 1962; Crofford and Renold, 1965). Fructose on the other hand is transported in a rapid insulin-independent manner, particularly when present in the medium in high concentration; moreover in this tissue fructose phosphorylation by hexokinase is not inhibited by free glucose (Froesch, 1965a; Froesch and Ginsberg, 1962; Ginsberg, 1965). 
Fructose is not only metabolized, but is also produced in specialized tissues such as the accessory reproductive glands of the male. Hers has detected two enzymes catalyzing the reduction of glucose to sorbitol and fructose, ie, aldose reductase and sorbitol dehydrogenase (Hers, 1960). Fructose appears to be the major source of energy for the sperm. The same enzyme system is also present in the brain and nervous system (Gabbay and O'Sullivan, 1968). The interesting hypothesis has been put forward that during hyperglycaemia sorbitol and fructose might be formed in excessive amounts in brain and nerve tissue. Due to the relative impermeability of the blood-brain barrier for fructose and sorbitol, these latter substances might be the cause of a relative hyperosmolarity in the brain during rapid lowering of the blood sugar and might be responsible for the cerebral oedema which is still one of the major causes of death during the treatment of diabetic acidosis (Clements, Prockop, and Winegrad, 1968).

\section{ESSENTIAL FRUCTOSURIA}

Essential fructosuria is a rare inborn error of metabolism which should be considered as a harmless anomaly rather than as a disease, since it does not cause any untoward signs and symptoms (Steinitz, Steinitz, and Mizrachi, 1963). Essential fructosuria is transmitted by an autosomal recessive gene and it is encountered almost exclusively in Jews. The enzyme fructokinase is lacking (Schapira, Schapira, and Dreyfus, 1961). Fructose is absorbed unchanged in a normal fashion from the gut, rising to very high levels in the blood, and approximately 10 to $20 \%$ is excreted in the urine (Fig. 2). Since the specific pathway of fructose is absent, it must be assumed that a considerable portion of fructose is metabolized by adipose tissue, as indicated by the fall of the free fatty acids during fructose tolerance tests (Steinitz, personal communication). The diagnosis of essential fructosuria is usually made by chance, often during screening for diabetes mellitus. Fructose in the urine may be picked up by any method based on the reducing property of sugars. Fructose gives a purple colour with resorcinol in acid, and its presence in biological fluids may be definitively proven by paper chromatography. The administration of fructose does not lead to any symptoms in patients with essential fructosuria, so that dietary restrictions are unnecessary.

\section{HEREDITARY FRUCTOSE INTOLERANCE}

CLINICAL CONSIDERATIONS The first description of 'idiosyncrasy to fructose' dates back to 1956, and

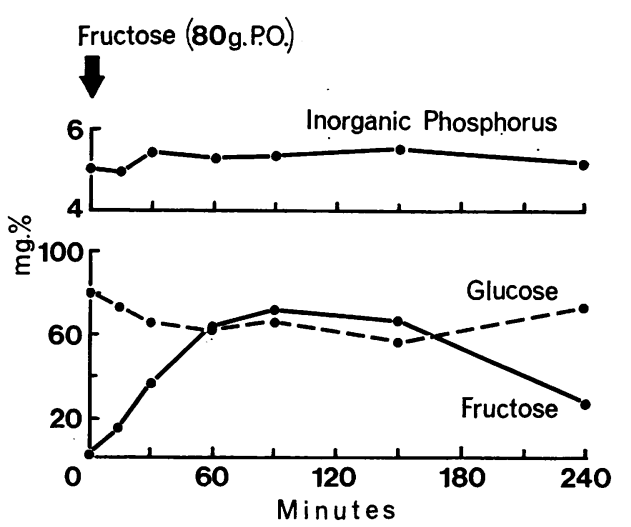

FIG. 2. Oral fructose tolerance test with $80 \mathrm{~g}$ of fructose in a patient with essential fructosuria. Glucose was measured by the difference between total reducing substances and fructose by the resorcinol method. The slight apparent fall of blood glucose may be explained by inadequate methods. Note the absence of untoward symptoms and the constant serum level of inorganic phosphorus. (We are indebted to Dr Stcinitz for permission to reproduce these results.)

was made by Chambers and Pratt in England (Chambers and Pratt, 1956). At the same time my colleagues, Professor Prader and Dr Wolf, and I studied our first family with hereditary fructose intolerance in Z.urich (Froesch, Prader, Labhart, Stuber, and Wolf, 1957). In contrast to essential fructosuria, hereditary fructose intolerance is a very serious condition which may lead to death in early infancy. The symptoms (Table II) usually appear when

TABLE II

SIGNS AND SYMPTOMS OF HEREDITARY FRUCTOSE INTOLERANCE

Signs and Symptoms

\begin{tabular}{|c|c|}
\hline $\begin{array}{l}\text { Beginning } 20 \text { Minutes after Oral } \\
\text { Fructose }\end{array}$ & Chronic Syndrome ${ }^{1}$ \\
\hline $\begin{array}{l}\text { Sweating } \\
\text { Trembling } \\
\text { Dizziness } \\
\text { Nausea } \\
\text { Vomiting } \\
\text { Various degrees of disturbed } \\
\text { consciousness to deep coma } \\
\text { Fructosuria } \\
\text { Hypophosphataemia } \\
\text { Fructosaemia (not excessive) } \\
\text { Aminoaciduria } \\
\text { Hyperbilirubinaemia } \\
\text { Rise in serum levels of hepatic } \\
\text { enzymes }\end{array}$ & $\begin{array}{l}\text { Failure to thrive } \\
\text { Jaundice } \\
\text { Hepatomegaly } \\
\text { Vomiting } \\
\text { Dehydration } \\
\text { Oedema } \\
\text { Ascites } \\
\text { Convulsions } \\
\text { Fructosuria } \\
\text { Fructosaemia } \\
\text { Hyopohosphataemia } \\
\text { Hyperbilirubinaemia } \\
\text { Rise in serum levels of hepatic } \\
\text { enzymes } \\
\text { Fibrosis or cirrhosis of liver } \\
\text { Aversion to sweet food } \\
\text { Lack of dental caries }\end{array}$ \\
\hline
\end{tabular}

${ }^{1}$ Most often during weaning when sucrose is added to the diet. 
the child is weaned and when sucrose or fruit juices are added to the diet. The earlier this occurs, the severer the signs and symptoms, which include failure to thrive, hepatomegaly, jaundice, ascites, oedema, fructosuria, aminoaciduria, and severe liver cell damage with a rise of the hepatic serum enzyme levels (Levin, Oberholzer, Snodgrass, Stimmler, and Wilmers, 1963). Convulsions are often seen. If fructose administration is continued, irreversible liver cell damage with fibrosis and cirrhosis may develop leading to cachexia, dehydration due to chronic vomiting and death (Sacrez, Juif, Metais, Sofatzis, and Dourof, 1962). Later, however, these children develop a strong aversion toward sweet foodstuffs containing fructose and thus protect themselves against the noxious agent (Froesch et al, 1957; Froesch, Prader, Wolf, and Labhart, 1959). Hence those who survive the initial severe disturbance due to the prolonged administration of fructose in early infancy usually recover fully and do not show any signs of definitive liver cell damage or of physical or mental retardation (Froesch et al, 1963).

The acute syndrome after fructose administration (Table II) consists of two types of reaction. Half to one hour after fructose administration the patient shows all the signs and symptoms of hypoglycaemia such as sweating, trembling, and a variable degree of disturbed consciousness (Fig. 3); hypoglycaemic coma may develop (Froesch et al, 1957). These symptoms are readily relieved by intravenous glucose administration. At the same time the patient complains of nausea and often vomits several times. It is probably the nausea and vomiting that induce the very strong aversion of patients with hereditary fructose intolerance toward all sweet foodstuffs containing fructose. Shortly after the ingestion of large doses of fructose the serum levels of the liver-specific enzymes rise and hyperbilirubinaemia, fructosuria, and aminoaciduria develop (Levin et al, 1963; Froesch et al, 1959). As in the case of essential fructosuria, only 10 to $20 \%$ of the ingested fructose is excreted in the urine. The biological half-life of fructose is somewhat prolonged. Sorbitol, which is metabolized in the liver by way of fructose, leads to the same symptoms (Froesch et al, 1963). Sorbose, another substrate of fructokinase, is phosphorylated to a lesser extent and its biological half-life is prolonged in patients with hereditary fructose intolerance. It does not lead to any of the above-mentioned symptoms, because accumulation of sorbose-1-phosphate is limited (Froesch et al, 1963) (see next section).

PATHOGENESIS OF HEREDITARY FRUCTOSE INTOLERANCE The primary defect in hereditary fructose intolerance is a deficiency of fructose-1-phosphate aldolase

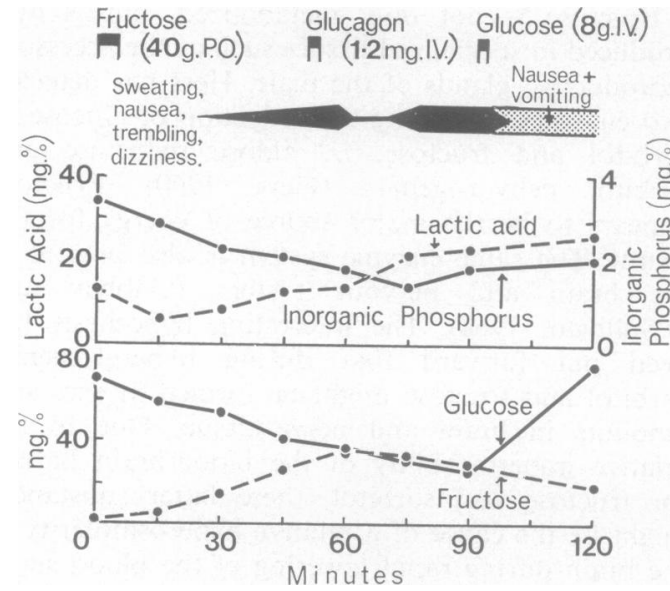

FIG. 3. Oral fructose tolerance test with $40 \mathrm{~g}$ of fructose in a patient with hereditary fructose intolerance. Note the progressive fall of blood glucose, unresponsive to glucagon, and the decrease of serum inorganic phosphorus. Glucose administration relieved the sweating, trembling, and disturbed consciousness, but nausea and vomiting continued, indicating that hypoglycaemia in itself is not the cause of the gastrointestinal symptoms.

(Hers and Joassin, 1961; Wolf and Froesch, 1963). Schapira, Nordmann, and Dreyfus (1968) believe that there is a mutation of the structural gene for the hepatic enzyme. Fructose can be phosphorylated normally by fructokinase to fructose-1-phosphate, but further metabolism of fructose-1-phosphate is blocked due to the absence of fructose-1-phosphate aldolase. Fructose-1-phosphate accumulates intracellularly in the liver (Milhaud, 1964) and leads to the above-mentioned symptoms of hypoglycaemia. However, the nausea and vomiting may be largely due to the accumulation of fructose-1-phosphate in the mucosa of the small bowel, because they may persist after relief of the hypoglycaemia (see Fig. 3); this possibility is not yet proven. The mechanisms responsible for the induction of hypoglycaemia are still a matter of speculation. At one time the hypothesis was put forward that the drop in serum inorganic phosphorus might reflect a depletion of inorganic phosphorus within the liver cell leading to an impairment of the phosphorylase action on glycogen (Froesch et al, 1959). However, hypoglycaemia could not be prevented by large doses of inorganic phosphorus administered intravenously (Nivelon, Mathieu, Kissin, Collombei, Cotte, and Béthenold, 1967). Although we do not know whether the administered phosphorus reached the crucial intracellular site close to the glycogen molecule and the phosphorylase, these findings make it unlikely 


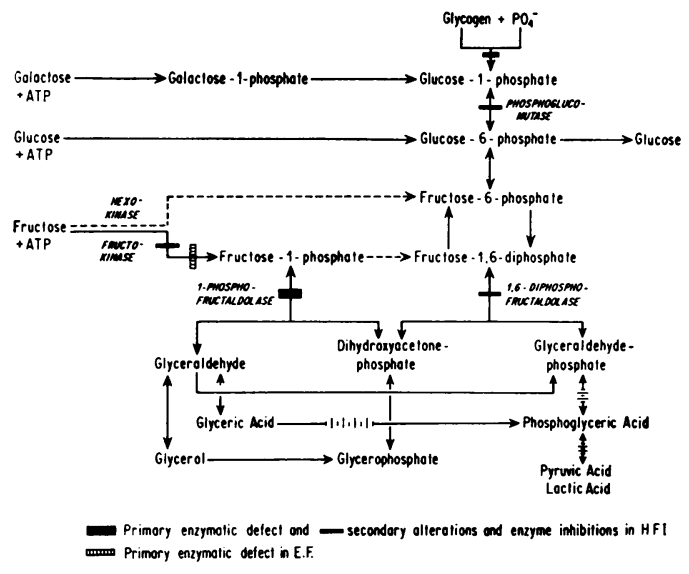

FIG. 4. Schemes of fructose metabolism in the liver and of the primary enzyme defects and secondary enzyme inhibitions in essential fructosuria and hereditary fructose intolerance.

that a lack of inorganic phosphorus is responsible for the inability of the liver to mobilize glycogen under these conditions. It must rather be assumed that the fructose-1-phosphate directly inhibits the action of phosphorylase on glycogen to form glucose-1-phosphate (Nivelon et al, 1967). Besides glycogenolysis, gluconeogenesis appears also to be blocked by fructose-1-phosphate.

We have shown that fructose-1-phosphate competitively inhibits fructose-1, 6-diphosphate aldolase (Froesch et al, 1959). Thus, the condensation of the two phosphorylated trioses to form fructose-1, 6-diphosphate may be impeded in the presence of large amounts of fructose-1-phosphate so that the synthesis of glucose might be blocked at this level. In this respect it is of interest that the hypoglycaemia caused by fructose in hereditary fructose intolerance may be alleviated by the administration of galactose (Cornblath, Rosenthal, Reisner, Wybregt, and Crane, 1963), but not by glycerol which has to undergo condensation to fructose-1,6-diphosphate by fructose-1,6-diphosphate aldolase (personal observations).

The proven primary enzyme deficiencies in essential fructosuria and hereditary fructose intolerance and the secondary inhibitions due to fructose-1phosphate accumulation are shown in Figure 4.

DIAGNOSIS OF HEREDITARY FRUCTOSE INTOLERANCE I wish to emphasize that the diagnosis of hereditary fructose intolerance is not difficult, but will only be made by those who are looking out for this disease. In this respect I would mention the recent publication of Black and Simpson (1967) which suggests that many babies and children with hereditary fructose intolerance are suffering from the toxic effect of continued fructose intake because they have been wrongly diagnosed as cases of pyloric stenosis, glycogenosis, or cirrhosis of unknown origin.

Since fructose by mouth always causes nausea and vomiting in patients with hereditary fructose intolerance we prefer the intravenous fructose tolerance test. A dose of $0.25 \mathrm{~g}$ of fructose per kilogram in adults and of $3 \mathrm{~g}$ per $\mathrm{m}^{2}$ in infants almost always causes hypoglycaemia and hypophosphataemia (Fig. 3) and thus establishes the diagnosis of hereditary fructose intolerance; in contrast, patients with essential fructosuria show little or no fall in glucose and no fall in phosphate (Fig. 2). Rarely the liver cell damage in hereditary fructose intolerance may be so severe that the amount of fructose phosphorylated by the liver may be too small to induce hypoglycaemia (Black and Simpson, 1967). In such infants the dose of fructose may have to be doubled in order not to miss the diagnosis. One large dose of fructose does less harm to these children than prolonged daily exposure to smaller quantities.

The ratio of fructose-1,6-diphosphate adolase to fructose-1-phosphate aldolase activity in a liver biopsy specimen may also be determined to clinch the diagnosis of hereditary fructose intolerance (Table III). This ratio is approximately 1 in normals

TABLE III

FRUCTOSE-1-PHOSPHATE ALDOLASE AND FRUCTOSE-1,6DIPHOSPHATE ALDOLASE ACTIVITIES IN THE LIVER OF PATIENTS WITH HEREDITARY FRUCTOSE INTOLERANCE AND NORMAL SUBJECTS ${ }^{1}$

\begin{tabular}{|c|c|c|}
\hline & Normal Subjects & $\begin{array}{l}\text { Hereditary } \\
\text { Fructose } \\
\text { Intolerance } \\
(n=10)\end{array}$ \\
\hline $\begin{array}{l}\text { Fructose-1,6-diphosphate aldolase } \\
\text { Fructose-1-phosphate aldolase } \\
\text { Ratio }\end{array}$ & $\begin{array}{c}229 \pm 107 \\
164 \pm 76 \\
1 \cdot 4\end{array}$ & $\begin{aligned} 114 & \pm 58 \\
13 \pm & \pm \\
8 \cdot 8 & \end{aligned}$ \\
\hline
\end{tabular}

${ }^{1}$ Bücher units $\pm \mathrm{SD}$.

and above 5 in patients with hereditary fructose intolerance (Wolf and Froesch, 1963; Black and Simpson; 1967).

Heterozygote carriers of hereditary fructose intolerance show no detectable anomaly of fructose metabolism. They cannot be detected by means of fructose tolerance tests. One would expect to find an intermediate ratio of fructose-1,6-diphosphate aldolase to fructose-1-phosphate aldolase somewhere 
between 1 and 5, but this has not yet been demonstrated due to the lack of biopsy material.

\section{FINAL COMMENTS}

I wish to finish by mentioning two facts which are of general interest. The first one concerns the complete absence of dental caries in older children and in adults with hereditary fructose intolerance (Cornblath et al, 1963; Froesch, 1965b; Marthaler and Froesch, 1967). These patients consistently avoid any sweet foodstuff containing fructose, sucrose, or glucose. In our view this proves that the development of dental caries is impossible when no monosaccharides and disaccharides are present in the diet. The second point concerns the role of sucrose in obesity. It would be unfair to those of you who believe that sucrose is the true evil of modern civilization if I did not mention that most patients with hereditary fructose intolerance are lean. However, I have personally seen one business woman from Munich with hereditary fructose intolerance who managed to be 20 to $30 \%$ overweight despite a very strict regimen containing no sugar whatsoever. This case unequivocally proves that it is perfectly possible to become obese without taking any sucrose in the diet.

\section{REFERENCES}

Adelman, R. C., Spolter, P. D., and Weinhouse, S. (1966). J. biol. Chem., 241, 5467.

Black, J. A., and Simpson, K. (1967). Brit. med. J., 4, 138.

Chambers, R. A., and Pratt, R. T. C. (1956). Lancet, 2, 340.

Christen, P., Göschke, H., Leuthardt, F., and Schmid, A. (1965) Helv. chim. Acta, 48, 1050.

Clements, R. S., Jr., Prockop, L. D., and Winegrad, A. I. (1968). Lancet, $2,384$.

Cori, C. F. (1925). J. biol. Chem., 66, 691.

Cornblath, M., Rosenthal, I. M., Reisner, S. H., Wybregt, S. H., and Crane, R. K. (1963). New Engl. J. Med., 269, 1271.

Crane, R. K. (1960). Physiol. Rev., 40, 789.

Crofford, O. B., and Renold, A. E. (1965). J. biol. Chem., 240, 14.

Froesch, E. R. (1965). Fructose metabolism in adipose tissue from normal and diabetic rats. In Handbook of Physiology, Section
5, adipose tissue, edited by A. E. Renold, and G. F. Cahill, Jr., p. 281. American Physiological Society, Washington, D.C. (1966). Essential fructosuria and hereditary fructose intolerance. In The Metabolic Basis of Inherited Disease, 2nd ed., edited by J. B. Stanbury, J. B. Wyngaarden and D. S. Fredrickson. p. 124. McGraw-Hill, New York.

-, and Ginsberg, J. L. (1962). J. biol. Chem., 237, 3317.

-, Prader, A., Labhart, A., Stuber, H. W., and Wolf, H. P. (1957). Schweiz. med. Wschr., 87, 1168.

,-- Wolf, H. P., and Labhart, A. (1959). Helv. paediat. Acta, $14,99$.

—, Wolf, H. P., Baitsch, H., Prader, A., and Labhart, A. (1963). Amer. J. Med., 34, 151.

Gabbay, K. H., and O'Sullivan, J. B. (1968). Diabetes, 17, 239.

Ginsberg, J. L. (1965). Z. ges. exp. Med., 139, 101.

Hardinge, M. G., Swarner, J. B., and Crooks, H. (1965). J. Amer. diet. Ass., 46, 197.

Heinz, F., and Lamprecht, W. (1961). Hoppe-Seylers Z. physiol. Chem., 324, 88.

- and Kirsch, J. (1968). J. clin. Invest., 47, 1826.

Hers, H. G. (1952). Biochim. biophys. Acta (Amst.), 8, 416.

- (1960). Ibid., 37, 120, 127.

, and Joassin, G. (1961). Enzymol. biol. clin., 1, 4.

and Kusaka, T. (1953). Biochim. biophys. Acta (Amst.), 11, 427.

Holzer, H., and Holldorf, A. (1957). Biochem. Z., 329, 283.

Kuyper, Ch. M. A. (1959). Proc. kon. ned. Akad. Wet., B. 62, 137.

Lamprecht, W., and Heinz, F. (1958). Z. Naturforsch., 13b, 464.

Leuthardt, F., and Testa, E. (1950). Helv. physiol. pharmakol. Acta, 8, c67.

-

Levin, B., Oberholzer, V. G., Snodgrass, G. J. A. I., Stimmler, L., and Wilmers, M. J. (1963). Arch. Dis. Child., 38, 220.

Marthaler, T. M., and Froesch, E. R. (1967). Brit. dent. J., 123, 597.

Mehnert, H., Mahrhofer, E., and Förster, H. (1964). Münch. med. Wschr., 106, 193.

Milhaud, G. (1964). Arch. bras. Endocr., 13, 49.

Morgan, H. E., Henderson, M. J., Regen, D. M., and Park, C. R. (1961). J. biol. Chem., 236, 253.

Nivelon, J. L., Mathieu, M., Kissin, C., Coliombel, C., Cotte, J., and Béthenold, M. (1967). Ann. Pédiat, 14, 817.

Penhoet, E., Rajkumar, T., and Rutter, W. J. (1966). Proc. nat. Acad. Sci. (Wash), 56, 1275.

Sacrez, R., Juif, J. G., Metais, P., Sofatzis, J., and Dourof, N. (1962). Pédiatrie, 17, 875.

Schapira, F., Nordmann, Y., and Dreyfus, J. C. (1968). Rev. frans. Étud. clin. biol., 13, 267.

_, Schapira, G., and Dreyfus, J. C. (1961-62). Enzymol. biol. clin., 1, 170.

Smith, L. H., Jr., Ettinger, R. H., and Seligson, D. (1953). J. clin. Invest., 32, 273.

Steinitz, H. Personal communication.

Steinitz, K., and Mizrachi, O. (1963). Schweiz. med. Wschr., 93, 756.

Wolf, H. P., and Froesch, E. R. (1963). Biochem. Z., 337, 328.

, and Leuthardt, F. (1953). Helv. chim. Acta, 36, 1463.

Yudkin, J. (1964). Lancet, 2, 4.

$\longrightarrow$, and Roddy, J. (1964). lbid., 2, 6. 